\title{
Concerns and Suspicions on a Questionable Science in the Era of Ideologies: The Hard Pathway of Comparative Education in Italy during the 1970s
}

\author{
Letterio Todaro \\ Università di Catania
}

\begin{abstract}
Up until the 1970s, comparative research on education had been scarcely developed in Italy. The rise of a general attention on the promising chances offered by the comparative inquiries in educational sciences was mainly due to the growing influence of several international institutions and organizations in framing a number of studies and reports on the educational process within a comparative perspective. However, the development of comparative education also met resistances and constraints in the Italian framework. A lot of critical voices rising from radical, neo-Marxist, and "not aligned" cultures questioned the alleged impartiality of the comparative discipline, expounding serious concern about the legitimacy of its scientific pretensions. On the whole, the outstanding critical views on the rise of comparative education fostered a wide suspicion of the influence of global agents in assessing the goals of education and particularly of the role of the main international organizations leading the strategies for global development.
\end{abstract}

Keywords: comparative education, globalization, critical pedagogy, neo-Marxism, Italy

ISSN 2560-8371

DOI: 10.24908/encounters.v21i0.14097

(C) Encounters in Theory and History of Education | 52 


\section{Les inquiétudes et soupçons au sujet d'une Science contestable dans une ère d'idéologies : le cheminement difficile de l'éducation comparative en Italie durant les années 1970}

\section{Résumé}

La recherche comparative en éducation a peu évolué en Italie jusqu'aux années 1970. A cette époque, le développement d'une attention générale à l'élargissement des connaissances offertes par l'enquête comparative dans le domaine des sciences de l'éducation a décollé grâce au succès de la publication d'un nombre croissant de rapports sur la situation de l'éducation dans le monde par quelques grandes organisations internationales. Cependant, la poussée vers la création d'un domaine d'étude comparative sur l'éducation a également rencontré de nombreuses résistances et contraintes. Un chœur cohérent de voix critiques du domaine des cultures antagonistes, radicales et néo-marxistes a remis en question l'impartialité alléguée d'une science comparée de l'éducation, en révélant également des doutes sur sa possible légitimité scientifique. Dans l'ensemble, ces voix critiques ont suscité de vives suspicions quant à la dépendance des objectifs de la recherche comparative en éducation par rapport aux programmes fixés par les gouvernements, suscitant de nombreux doutes quant au rôle politique joué par les principales organisations internationales dans l'orientation des stratégies mondiales de développement.

Mots-clés: éducation comparée, mondialisation, pédagogie critique, néo-marxisme, Italie

\section{Preocupaciones y sospechas acerca de una ciencia cuestionable en la era de ideologías: el camino difícil de la Educación Comparada en Italia durante los años setenta}

\section{Resumen}

Hasta los años setenta del siglo XX, las investigaciones comparativas sobre educación apenas se habían desarrollado en Italia. El aumento y promesas de cambio educativo que generaron las investigaciones comparativas en ciencias de la educación se debieron principalmente a la creciente influencia de varias instituciones y organizaciones internacionales en la elaboración de una gran cantidad de estudios e informes sobre el proceso educativo desde una perspectiva comparativa. Sin embargo, el desarrollo de la educación comparada también encontró resistencias y 
limitaciones en el marco italiano. Muchas voces críticas surgidas de culturas radicales, neomarxistas y "no alineadas" cuestionaron la supuesta imparcialidad de la disciplina de la educación comparada, lo que planteó una seria preocupación por la legitimidad de sus pretensiones científicas. En general, los notables puntos de vista críticos sobre el aumento de la educación comparada fomentaron una gran sospecha acerca de la influencia dada por los agentes globales en la evaluación de los objetivos de la educación y particularmente sobre el papel de las principales organizaciones internacionales que lideraban las estrategias para el desarrollo global.

Palabras clave: educación comparada, globalización, pedagogía crítica, neomarxismo, Italia

\section{Introduction}

The development of the topic in this paper requires a brief preamble to clarify some theoretical assumptions. In a recent work on the evolution of the education systems and school curricula in Spain between the 1960s and 1970s, Mariano GonzàlezDelgado and Tamar Groves highlighted a rather interesting subject in terms of historical research about education problems (Gonzàlez-Delgado \& Groves, 2017, pp. 74-75). The interest raised by the two authors' theory depends on the fact that it seems to be applicable to a broader international framework, beyond its efficacy value in relation to the analysis of the Spanish case. More specifically, the authors developed their essay and called on an understanding of how, especially starting from the 1960s, the education systems in the Western area were shown to be modelled with increasing uniformity and to express a significant tendency to mutual integration.

This status is well represented in Gonzàlez-Delgado and Groves' work, and may actually be observed when we consider how, starting from that period, the educational systems in different highly developed Western countries adapted to common benchmarks and set up their future planning based on general and basically superimposable platforms. Also, it seems quite clear that the characterization of the objectives and aims to be achieved begin through the definition of increasingly approved conceptual frameworks.

An overview shows quite clearly that starting from that period, the description of the developmental lines on which educational policies are organized at the international level has tended to manifest strong analogies and signs of similarities to a common basic inspiration (Beech, 2009). The guiding role of some major international organizations like UNESCO, for instance, capable of structuring lines of action and coordinating programmes of action in the field of education at a trans-national level, represents a decisive factor in the drive given to this trend toward a general uniformity of educational systems (Duedahl, 2016). 
The projection horizon of the analysis of this paper is represented by the field of hypothesis highlighted above. Basically, it involves determining whether the Italian case also shows signs of correspondence to the situation described above. In particular, the intention is to detect the action of some significant elements, identifiable as the "warning signs," able to demonstrate whether similar trends consolidated also in Italy in that period.

The primary issue analyzed in this regard is mainly concerned with verifying whether and to what extent the organization of a scientific framework focused on comparative investigations about education in Italy may be a result of the contemporary rapprochment of international training policies, and if the increased presence of major international organizations played some controlling role in terms of these aspects. Such organizations were potentially influential in the outlining of certain general guidelines that helped to raise awareness of the culture of education in Italy, to turn it towards a greater connection with the international systems and consequently to guide the prospects of its scientific research.

Going even further into detail, we need to verify whether and to what extent the strengthening of international coordination was able to produce significant effects in order to foster the deployment of investigation patterns of a comparative nature, to be applied to the analysis of development processes related to the field of education (public education, and also the study of school systems and training). However, on the basis of this work plan, other possible consequential issues must be brought to the table.

In fact, it must be acknowledged that a strong drive in the development of comparative studies in education came about because of the heightened conditions of integration of the Italian system within international frameworks linked to the systemic organization of a large grouping of countries in the Western area. It thus becomes necessary to also examine what the reactions were, as well as the responses and effects of these components in the Italian context. More specifically, we should verify whether these trends started only in the sense of creating enthusiasm in the name of educational research investments towards comparative profiles that inevitably led the Italian situation to be seen as unavoidably entwined in a common trans-national destiny, or if antagonistic effects and responses were also observed.

In this context, the historical investigation of the critical transition phase characterizing the evolution of pedagogical culture and the apparatus of educational sciences in Italy between the 1960s and 1970s holds interesting points for reflection, precisely to the extent that it proceeds to come across the phenomenon related to a nascent comparative science of education struggling to make its way through. From this perspective, it comes to taking account of a particular historiographic issue, which invites the reading of history to be sensitive to the recovery of a range of points of criticism, dissenting voices, or at least to those expressions denotative of the attitudes of "suspicion" that became opposition energies with respect to the tendencies 
ingrained at that time. Moreover, in this sense, it is important to recover to the historical view the area occupied by the positions that tended not to be aligned to the organization of the current cultural mainstream: divergent positions incorporating, within the various modes and forms of theoretical categorization, all of the fears, worries, and concerns that animated the parterre of voices that in that time ended up standing as "not aligned" and discordant. With this, it should be made historically clear that there were also forms of opposition and resistance against the strengthening of attitudes and habits supporting the use of comparative methods within the structuring axes of knowledge about education, as well as against the obvious utility and convenience entailed in the use of these studies.

Nevertheless, in the context of the progressive expansion of comparative research plans in the field of educational processes, there were grounds of distrust, brought about by the detection of more than one reason for ambiguity underlying the emergence of those phenomena. Indeed, the suspicion that "political" elements may have been hidden behind the growing interest in the use of several comparative tools in the study of learning processes represents quite an interesting topic to be considered in the historical analysis, and in order to appreciate the complexity of this particularly sensitive transition time in the area of Educational Sciences between the 1960s and the 1970s.

\section{The Emergence of Comparative Studies in the Educational/Pedagogical Area in Italy in the 1970s: Between Enthusiasms and Resistances}

At this point, in order to bring in the merit of the question, the first useful step is to outline the descriptive framework where the development of comparative studies in Italy is placed at the turn of the 1970s, and the correlative organization of a real disciplinary area to be identified through observation of the construction of a specific scientific domain referred to as "comparative education." In order to appropriately introduce the profile of this subject, it will be useful to start by exploring the existing critical literature on the topic. For example, it may be useful to begin by considering some indications suggested by two authoritative experts in the historical developments of Comparative Education in Italy, Carla Callegari and Giuseppe Zago.

In some recent works, both Callegari and Zago have expressly defined the historical phase starting from the 1960s and that consequently progressed towards the 1970 s as the most important phase of arrangement and maturation for the physiognomic organization of a comparative discipline in Europe regarding the area of Educational Studies. This situation, mostly affecting the wider area of Western Europe, also explicitly refers to Italy (Zago \& Callegari, 2016, p. 15). 
According to a growing movement in the 1960s, even in Italy, the field of comparative education studies tended to become stronger. The rapid growth of this commitment was mainly due to the contemporary strengthening of connections with some of the new international organizations, both European and global, created with the main purpose of mitigating the nationalisms that had led to the catastrophe of the Second World War (Tosi, 1999). Among them, we should mention, above all, UNESCO, the European Council, the European Economic Community and the OECD, which were starting to operate more and more actively within the international area where educational strategies and policies were interlinked.

Callegari and Zago highlighted the Italian situation even more specifically. They demonstrated how a powerful boost to the structuring of the comparative analysis dimension in the framework of the educational sciences, which proceeded through the mobilization of scholars, already alert and sensitive to such a research perspective, used in various forms of participation and contributions inside research and study organizations coordinated within some frame of European synergies.

In this respect, various contributions are mentioned, beginning in the 1960s and then again in the 1970s, offered in different stages by eminent scholars of Italian pedagogy to the research and work plans of the Comparative Education Society in Europe: from Luigi Volpicelli to Mauro Laeng, from Aldo Visalberghi to Benedetto Vertecchi.

In any case, the increasingly visible intervention of those large supranational organizations (UNESCO, OECD, Council of Europe) in dictating the fundamental and large scale guidelines on the strategies of training, especially to tie both the themes of education and of economic growth and development in a continuous perspective, ensured that in that period a collaborative vision of the education issues at the transnational level began to unfold; such a vision is increasingly projected to understand its own horizons within a "global," or world system (Callegari, 2017).

In 1973, the publishing company Armando, one of the main Italian publishers engaged in the publication of papers in the area of educational science and one of the first to begin to put together collections of volumes objectively belonging to the area of comparative education (Zizioli, 2011), published the Italian version of the major Report on the strategies of education (1972), commonly referred to as the Faure report (UNESCO). It was precisely when this very significant document for the configuration of a widely impactful literature among the scholars who were experts in the educational sciences appeared that ambivalent positions began to be outlined, of great enthusiasm and adhesion, but also of discretion and concern (Callegari \& Gaudio, 2018, pp. 7-9). In fact, since the Faure report reception was not marginal, edgy questions were often brought up.

To what extent might the systemic analysis and the conclusive indications presented in that document guarantee reliability? How did the sensitization to the use of comparison come out as ideologically oriented? Where did the resulting acceleration 
in favour of the use of comparative study lead to and to what kind of significant background? Did it push toward the will to implement an eminently cognitive function useful to enhance the information resources available to the sciences of education? Or did it rather strengthen the management function entrusted to the large supranational agencies - thus implicitly legitimating their pre-eminence in setting programmatic visions on the great educational questions, following pathways that went beyond the centrality of a pedagogy ratio - to endorse a political ratio, always more effective in planning the interventions that would characterize the development of the training systems within a geopolitical vision?

A historical look into these doubts would seem to be very helpful in order to try to bring to light the meaning of those signals of ambiguity and reserve, of the uncertainty that accompanied the consolidation of comparative research and the acquisition of a more visible space for comparative education studies at the beginning of the difficult 1970s in Italy.

\section{Concerns and Suspicions on the Beginning of Comparative Discipline in Italy in the Area of Educational Sciences in the Early 1970s: The Testimony of Giovanni Gozzer}

First, we will start going deeper into the issues highlighted here and identify the circuits of interest that point out its value of documentation and testimony with the purpose of understanding the historical situations of that period. The proposal herein suggests trying to probe the two paths of preferential research, which are interestingly comparable for their ideological/cultural diversity.

The first area of investigation is the remarkable work developed by Giovanni Gozzer, a scholar of Catholic formation, who directed for several years the European Centre of Education in Frascati. In that particular historical transition, he was most likely among the figures with more connections to international studies structures and organizations concerned with the problems of school and education. Besides, he had been in charge several times of functions of institutional representation within the international commissions (Gaudio, 2018). In 1973, Gozzer published a very interesting paper with regard to the core analysis in the present work. Specifically, he made available to the Italian pedagogical culture the first synthesis profile focused on some important national and international reports on the theme of education that had emerged just at the turn of the 1970s. It was a sort of reasoned compendium of texts drawn from the collection of six reports, accompanied by a suitable commentary profile and discussion notes to be submitted as an incentive to public debate.

The volume's significant title was // Capitale Invisibile. Through a critical analysis of a series of contemporary reports on education coming from the different institutions and organizations, Gozzer reported well on how the generally prevailing cultural 
paradigm at the international level that was expanding in terms of the discussion on contemporary education tended to overlap with a macrofinancial rationale. ${ }^{1}$ Thus, the issue of training more and more coincided with a problem tending to shift its centre towards the economic territory - "the invisible capital." However, this movement, now in its outlining stage, also aimed at expounding education as becoming a socially opposed theme; indeed, one could see it as "the hottest reference point in the entire range of social transactions" (Gozzer, 1973, p. 8).

To understand the inspired criticism that motivates Gozzer's work, it is enough to remember the polemic comments he raised regarding the conclusions of the FaureUnesco report. Gozzer considered the document as not entirely convincing, and as meant to feed an easy optimism on the demiurgic role attributed to education. In his view, the report contained too many exhortative suggestions and was "charged" with giving rise to a sort of futurological utopia based on no means of certain projections or of predicting forecasts of still evolving social phenomena. Finally, it showed a relationship substantially arranged in the prominent perspective of a sociological analysis, but as such was not able to return to the argument of a clear pedagogical "ratio" and was therefore not easy to identify, or represent a comfortable possibility of self-recognition in its rationale for the education professionals.

However, the interesting part in the critical profile provided by Gozzer went beyond the importance of these limits about the analysis of the dossiers on education provided in the context of comparative discussion by large international organizations. Beyond what could be acquired through the data collection to be objectively found in those documents, in the background, there is still the hypothesis of a "suspended judgment," dictated by the presence of at least four major alternatives to each other's cultural options, which made any conclusion in terms of formulating a final assessment complicated per se. Among the following four main models that led to the attribution of a different meaning to the idea of "education/training system," Gozzer briefly distinguished them as:

the traditional-European (containing the implicit predilection for a model of elite formation, and therefore structurally oriented to maintaining a function of social selection);

the American-democratic (based on the "moral" principle of ensuring equal conditions with respect to the opportunities for individual development);

the ideological-competitive (i.e., the Soviet Union one, based on the rigid compliance with the State ideology and the tough competition of the school intelligences);

and, finally, the so-called non-school (i.e., the Chinese-Maoist one, that is, a model which delegated the responsibility of the educational functions to the sites of direct 
production - factories, industries, farms - and reabsorbed education in the ways of development, both formal and informal, of the socialist community) (Gozzer, 1973, pp. 26-30).

Of course, other alternative models were starting in the background, including, for example, the Latin-American one, following the Freire style, also betting on the deinstitutionalization of education, and on widespread training within the communities of life, to suggest the myth of the new society to come as the organization of a great educational community (Gozzer, 1973, pp. 147-163). Highlighting the presence of at least these four or five alternative and immeasurable training models in the background consequently fuelled a more general awareness of the impossibility of narrowing down the categories of pedagogical significance within technical frames.

Beyond what was documented by UNESCO and other supranational bodies, the way for possible continuation of the results of their analysis towards different objectives and towards the choice of potentially inconsistent operational programs remained open. This happened because in the background the possibility persisted of giving rise to projections substantially divergent on the proposition of goals to be achieved in the near future, due to the identification of different paradigms of development. Here we can see the importance of the position highlighted by Gozzer for the purposes of this analysis: a position not devoid of skeptical and dramatically doubting drifts regarding the so to speak technical directions coming from large international reports on education, and on the possibility of finding immediate solutions to education through the use of a merely technical perspective, starting from the use of new comparative tools of investigation.

Indeed, all those different reports presupposed more or less implicitly a reformminded intention (Palomba, 2011, pp. 37-38). Yet, given the analysis of the situation observed and studied from time to time, consequent remedies were suggested. At this point, as argued by Gozzer, reforms guided and controlled by the public hand became impossible, because no socio-political body was in the position to find unanimously approved answers to situations that may all have had countless and equally valid answers. A single answer imposed "from above" did not seem possible at all.

One substantial difficulty was realized and identified: the exhortative rationale, that of advice, of planning that inevitably innervated the great international documents collided with the awareness of the immeasurability of a different series of pedagogical models that were all marking, on their own, different destinies for a possible future education.

The sense of opening up to diriment dilemmas became all the more obvious, as one realized to be in a "middle" era: an epoch marked by the projective configuration of various orders of possible social transformation and still facing a difficult wade, marked by the insistence of great perspectives on education within a "indecisive" condition, due to the possibility of pursuing virtually chosen options. 
Furthermore, among those radically alternative models, those that were more explicitly oriented to the utopia of the educating community seemed to generate a strong, powerful and urgent challenge. Indeed, they aimed at promoting a possible operation of redetermination of the meaning to be attributed to the processes of growth and development within the liberal/capitalist systems. Those models could anticipate possible adjustments and work plans open to the challenges posed on the ground of educational programming, due to reasons not merely attributable to the authority of some technical paradigm.

From this perspective, the prominence of levels of cultural challenge was especially caught, motivated by the meeting with alternative and not at all negligible reasons; for instance, ethical reasons such as those standing out strongly in the name of the possibility of developing a democratic system based on the values of communitarianism, i.e., based on the ability to foster strong values of social cohesion and solidarity.

Therefore, it was precisely the suggestions coming from the models of the Chinese Revolution on the one hand, and those coming from Latin-American emancipationism on the other, that bookmarked the conditions of a greater challenging of all possible premises (Olmos \& Torres, 2009). And, of course, the more explicitly critical opinions expressed by those models were to insist on the signal of resistance and irreducibility, against the more or less concealed dirigism contained in the reports of the international organizations and against the idea of an aseptic use of the comparative methods within the scope of pedagogical sciences.

\section{Skepticism and Grounds of Opposition in the Face of the Beginning of the Comparative Discipline in Italy in the Area of Education Sciences in the Early 1970's: The Area of the Critical-Radical Cultures}

Considering the emergence of a degree of polemical allegations and the widening of skeptical positions concerning the rise of certain patterns of pedagogical comparison, at this point it is worth focusing carefully on a pedagogical area of discussion markedly inspired by an orientation of "protest." It is about directing attention toward an area of critical reflection and culturally resistant with respect to all those forms of discourse that seemed to want to indulge the prominence of new strong powers, interested in directing the programming of education training through the occupation of the field of the Educational Sciences. It is worth giving some consideration to the area of debate that, at that time, became the representative of forms of "critical-radical" and "nonaligned" pedagogy with respect to the growing cultural mainstream (Cambi, 1987).

In this sense, a possible and virtually useful course of analysis to enter into the factual profiles of such a history is obtained, for example, through the exploration of the paths connected to the publication of the series of studies of Educational Sciences 
titled II Puntoemme (Monti, 2013). In this regard, first of all, we need to remember the importance of this editorial series with respect to the ability to summarize an entire area of critical/iconoclastic thinking on the issues of education in Italy since the beginning of the 1970s (Terrusi, 2019, pp. 171-172).

The series of pedagogical studies published by Emme Edizioni has a rather interesting clue in its function to retrieve the reconstruction of the historical debate of that time, as well as the entries of that area of pedagogical culture that deployed in a strongly critical way against the assumptions of globalist capitalism, against the aggravations of individualist liberalism, and against the development models based on a merely economic rationale. It interpreted a cultural orientation that operated in the big tracks of Marxist reconsideration, and that, when reasons rose for resistance against the arrogance with which, in several areas of cultural and social life, the logic of the market had imposed itself, also added elements of harsh criticism towards the various forms of authoritarian culture that traditionally intervened to mark the classic debate on education. The recovery of such a space of critical reflection in the historical analysis may allow us, therefore, to find an important piece to reconstruct the complex picture of that period, and in many ways also characterized by the expression of forms of cultural antagonism - or better to say, characterized by the radicalism by which some forms of "anti-system" cultures were to express themselves.

So far, we have to recall the relevance of an area of "counter-culture" largely derived from the large protests of the late 1960s, and around which anti-capitalist instances, utopian suggestions of a socialist nature, libertarian drives and revolutionary urges had gathered (Cagnolati, 2019). The development of this area of critical pedagogy thus became an important voice in the process of disclosing the several collusions between the hegemonic cutural models in education and some cultural groundings of authoritarian inspiration scarcely sensitive to the values of democracy. This area of the pedagogical debate generated important critical insights about the educational institutions' poor awareness of the real educational needs of society. Such an unveiling function was destined to become more effective during the 1970s, when the structures of authoritarian pedagogy began to collapse.

With specific regards to our discussion, the line of thinking demonstrated in the papers that appeared in the series of studies // Puntoemme was quite interesting because it marked, on the theoretical side, the front of the attestation of the type of more marked suspicions against the evaluations on the conditions of education that were pronounced in the large reports and packaged by the international organizations. They were rejected because of coming "from above" and bearing their allegedly obvious "authority"; as a consequence, they were distanced and far from accepted in adaptive-passive terms.

In this regard it may be enough to provide some suggestive examples. First of all, inside this polemical area of pedagogical feeling, a way to reject the viewpoint generally adopted in the international reports, or anyway to interpret in a different way 
the drive arising there from the organization of a comparative vision on the major problems of education, was to focus on those global situations more capable of indicating the need for a problematization of the idea of "development": China on one side, Africa on the other. For this purpose, we refer particularly to some books clearly addressed in an alternative sense by Lucio Del Cornò, a non-academic sholar, active in the Communist Left environments, and the author of several articles for the main Review of Educational Culture converging to the positions of the Italian Communist Party, which is the "Riforma della Scuola" (Alba, 2014): the volumes appeared in the series of studies II Puntoemme. More specifically, these are works such as Esperienze pedagogiche in Cina (1974) and Esperienze pedagogiche in Africa (1976).

The first reflected the infatuation with that myth of the Chinese Revolution, which in the first part of the 1970s - as appropriately recalled by Angelo Gaudio in one of his recent studies (Gaudio, 2018, p. 24) - was a transversal phenomenon in the Italian culture, even beyond the neo-Marxist and Maoist components. Although of course it found a particular resonance in the left communist circles and deeply influenced the fantasies of the intellectuals belonging to a socialist universe that in those years was particularly sparkling and in full fibrillation (Ventrone, 2013; Niccolai, 1998; Perotti, 1981).

Based on that infatuation, the Chinese revolution was interpreted as the matrix of a radically alternative education project, which, seen from this side, i.e., from the West, could indicate again the great utopia of incorporating education into the organization of social life. With the Chinese model in mind, the fictitious myth of the spontaneous training generativity of the educating community was advanced: the myth of a possible liberation of education from a necessary inclusion in models of institutionalization, so as to open its flow to terms of free diffusivity in all the spaces, the places and the forms of collective life, starting from work.

The second study focused on Africa, a cultural and geographical area taken into consideration as a term of identification of a contrastive signal, which per se referred to the unconditional denunciation of the continuity of a project of westernization and hegemonic control of continents formerly under colonial rule and now placed "under protection" (Matasci, Bandeira Jeronimo, \& Gonçalves Dores, 2020). According to the author, the examination of the conditions concerned with the fate of education and the development plans of the educational policies for Africa could show exactly how, instead of leaving space to a process of progressive decolonization, the fate of the African Continent was deceitfully being bound to the assimilation of a development model decided elsewhere.

And then, the editorial presentation of this volume, made by Lucio Del Cornò, was particularly eloquent, explicitly polemical and critical on the great problems of postcolonial Africa and on the need to return to Africans their perspectives of development, through the promotion of education, training, and school programs, the way it was presented to the readers. In fact, on the back cover, it was openly declared that the 
estrangement from those analysis models could in any way compare to the nature of those studies that descend from the "foolish ambitions as a scholar of comparative pedagogy" (Del Cornò, 1976).

Ultimately, the Marxist critical pedagogy moved "from the left" in order to develop a complaint that was intended to include, in one and the same act of polemical refusal, both the conclusions of the international relationships and the organization regulating the nascent comparative studies, at least as they seemed to take form and outline their procedural schemes (Malizia, 2008).

The sense of such a background setting, openly suspicious of the configuration of a comparative education science, came even more explicitly to light in one chronologically successive volume still belonging to the same series, II Puntoemme. We refer here to one of the first comprehensive studies by Corrado Ziglio, a volume promising to suggest a purely "epoch-making" comparison between capitalist and socialist models: Sistemi politici e strutture scolastiche. La scuola secondaria superiore in Europa tra socialismo e capitalismo (1977).

The study opened with the development of a controversy against the studies of comparative pedagogy actually accused of being pseudo-studies: absolutely partial studies, where the reference to the partiality there seemed to just refer to the narrowness of the field that they were able to represent, but above all to the partiality of the scientific model identified (studies purely based on the collection of quantitative data, usually ending in the summary tables, and ipso facto, legitimating a technicalpragmatical pattern of rationality). Studies were also able to highlight an organization of analytical apparatuses supported by scientific methodologies, but unable to represent a depth of critical problematization on the analyzed problems.

According to the author, the approach favoured by the nascent comparatistics seemed to be entirely unsatisfactory; it gave rise to studies which were mainly limited to describing a state of affairs, but without wondering about the why of that state of affairs (Ziglio, 1977, p. 5). Even more explicit and harsh was the criticism against the dossiers issued by the major international organizations such as UNESCO-BIE, the Council of Europe, and the OECD, although they presented themselves as the most serious and credible institutions for dealing with topics concerning comparative pedagogy. In the author's opinion, these organizations, born with the intention of rendering to the governments a service in the field of education, administration and school planning, were nothing but "parrots" of the same governments, since the data they collected and on which they developed their dossiers came exactly from government sources. So, in the end, these organizations found themselves processing data already filtered at the origin and that, according to the critical viewpoint advanced by the author, seemed to hide a control activity carried out "at the source," or in the best scenario had showed a poor reliability. In short, it was not a question of highlighting only a methodological-technical bias, but mainly a bias related to being prejudicially "biased." 
It was a question of uncovering "upstream" the organization of a comparative area perfectly modeled on pre-packaged interpretative schemes, per se oriented to represent a certain vision of reality and to justify the rationale of the interventions considered necessary by the international "powers." It was also a question of rejecting a comparative pattern model that presupposed either objectivity or a mere technical neutrality on which it was expected to legitimize the institutional prestige of contracting authorities, obviously influenced by political orientations.

Finally, the issue was to highlight the bias inherent to a scheme that simplified the perception of the matters concerned with the planning of intervention on the systems of education in the school, always from a top-down perspective angle, as if it were constantly to plan something that then had to descend from above. That perspective didn't take into account the social base and all of the actors who, from time to time, could have triggered a movement of change starting "from below."

The formulation of those reports legitimated in the field of education a leadership always starting from entities who were "at the top": international institutions, international regulatory bodies, governments, and ministries. Instead, any possibility of rethinking the change in the standard of assessment of the training systems at the international level, according to the viewpoint possibly suggested by the actors who worked "from below," was shut out. It seemed especially regrettable as a way of expropriating the decision-making ground in the area of education and of subtracting values of real democratic participation in the governance of the school system, downgrading to a level of executors the function of those who had the right of speech, opinion and intervention. The process started from the same categories of teachers and education professionals, but excluded from real participation in the democratic decision-making the voices belonging to the territories, social forces, families, groups and spontaneous movements, of which every sign of real presence as parties concerned in the intervention on social transformations activated via the educational path was actually neutralized.

Lastly, Ziglio noted polemically how those international documents, which consequently were meant to inspire and shape the profiles of a certain theoretical scheme applicable to the study of comparative education, were full of moralism, of easy exhortatory rhetoric, as if a deed of trust and the sum of good intentions towards a principle of international collaboration could suffice to solve the big problems that arose on the horizon of comparative education, in a world otherwise marked by the worrying prospect of increasing inequalities and inhomogeneities (Ziglio, 1977, p. 10). Those documents suggested and indeed worked intentionally to feed the masses with a naive confidence that the solution of the big problems in the future of education would come from a sort of "magnanimity" act by the government leaders. This is proved by the feeling of concern expressed by governments and it is widely reflected in the writing of international documents and also encouraged to change in view of a generalized progress. Concerns and exhortations, which, in fact, had no other result 
than projecting the expectations of an education capable of intervening for the creation of a greater justice and fairer world within an illusory and fictitious sphere of "good intentions."

Thus, there was a presumption of reliance on a sort of "optimism of trust" that acted as a generic ideological glue to incardinate the very ground of comparatistics within those Western civilization mythologies that, ultimately, would contribute to depotentiate the development of all alternative and critical thinking. It was, in no uncertain terms, a heavy rejection of the "nascent" comparative discipline, at least in the ways in which it seemed to mould itself as a field of research obedient to higher system logics.

\section{Conclusions}

In conclusion, the analysis developed so far leads us to gain a complex vision of the cultural conditions that characterized the advent of education comparative research in Italy in the 1970s. On the wave of the growth of some basic trends, characterized by increasing integration of training policies and by the increased presence on the scene of international organizations, the influence towards the strengthening of an internationalist orientation was certainly significant, and this was also an important support for the strengthening of the comparative studies area in the field of the educational sciences.

However, the dark shadow of the ideological conditioning coming from the greater protagonism of the supra-national agencies at the level of the culture of education also contributed to the aggravation of a theoretical dispute between positions already structured by the logic of capitalism and positions differently oriented in the political and cultural sense, which were alternative and resistant, and also conditioned by certain reserves of the "moral" order towards the acceptance of that background pattern.

In this respect, the historical survey of the first beginnings of the comparative discipline in Italy in the pedagogical field becomes significant insofar as, through it, we are able possible to grasp the importance with which the solidity of an ad hoc historical issue is highlighted. The issues it brings to light cannot be underestimated in that they have to be examined in their specific terms, especially in relation to the reporting of some kinds of cultural suspect or cultural emerging in the face of what could also appear as the result of the enlargement of an improper "hand" coming from an outside territory. That is to say, in the face of what could appear as an emanation effect from a powerful political and cultural superior system, which is now presented as more and more interfering and active precisely in the area of education.

In this sense, the establishment of the "comparative" inside the cornerstones of the education knowledge could otherwise result in the perception of the extension of some 
more or less legitimate disciplinary embrace, because it is mainly coming from the areas of knowledge embedded within environments related to the economic science and to the social and political sciences. These signals often revealed themselves as equivalent to the manifestation of a potential full of ambiguity, if not downright distrust, to the extent that, around the unfolding of these dynamics, it seemed possible to identify the projection of the growing interest - perhaps even of the appetites - on the areas of training: appetites belonging to the planning of economic policy, the interests related to the design of the international cooperation policies, and the delineation of systems of consultation in general development policies.

From such a vision angle, technically it did not seem out of place to wonder whether the activation of the comparative dimension, by itself obviously useful in its most evident results, was hiding the signal of the progressive assimilation of the pedagogical/educational competence areas inside other spheres. At least, it could cast doubts on the possibility of a growing subjection of the pedagogical territory to the influential weight of external logics, perhaps even not completely creditable to fully understand dealing with educational/training issues.

\section{Note}

1. The documents considered by Gozzer were more precisely: the Frascati report; the Madrid report; the James and Joxe reports; the Faure report; the Perkins-MC Murrin report; the Reimer and Illich reports/messages. In the Appendix, he also added a text by J.S. Bruner on the conditions of education in the contemporary world, in view of the announced publication of the Italian translation of The relevance of education, still with the publisher Armando.

\section{References}

Alba, L. (2014). "La rivista Riforma della Scuola nel decennio delle riforme mancate, 1968-1980." diss. Università di Firenze. Accessed May 24, 2020.

https://www.academia.edu/33263891/La_rivista_Riforma_della_scuola_nel_decenni o_delle_riforme_mancate._1968-1980.

Beech, J. (2009). Who is Strolling through the Global Garden? International Agencies and Educational Transfer. In Cowen, R., Kazamias, A.M., (eds.). International Handbook of Comparative Education. (pp. 341-358). London - New York: Springer.

Cagnolati. A. (2019). Tra mitopoietica e ribellione. Giovani, formazione e controcultura negli anni Sessanta. In Madrussan, E. (ed.). Crisi di cultura e coscienza pedagogica. Per Antonio Erbetta. (pp. 39-48). Como-Pavia: Ibis.

Callegari, C. (2017). L'educazione comparata nell'epoca globale: la tradizione italiana e le prospettive future. Studium Educationis, XVII (2), 93-104. 
Callegari, C. \& Gaudio, A. (2018). Problemi e prospettive dell'educazione comparata oggi. Rivista di storia dell'educazione. 5(2), 7-13. https://doi.org/10.4454/rse.v5i2.

Cambi, F. (1987). La sfida della differenza: itinerari italiani di pedagogia critico-radicale. Bologna: Clueb.

Del Cornò, L. (1974). Esperienze pedagogiche in Cina. Milano: Emme Edizioni.

Del Cornò, L. (1976). Esperienze pedagogiche in Africa. Milano: Emme Edizioni.

Duedahl, P. (ed.). (2016). The History of Unesco. Global Actions and Impacts. London New York: Palgrave Macmillan.

Gaudio, A. (2018). Il discorso sull'educazione comparata in Italia dopo la seconda guerra mondiale: il caso di Giovanni Gozzer. Rivista di storia dell'educazione. 5(2), 17-28. https://doi.org/10.4454/rse.v5i2.163.

González-Delgado, M., \& Groves, T. (2017). La enseñanza programada, la UNESCO y los intentos por modificar el currículum en la España desarrollista (1962-1974). Espacio, Tiempo y Educación, 4(2), 73-100. doi: http://dx.doi.org/10.14516/ete.186.

Gozzer, G. (1973). Il capitale invisibile. Rapporti nazionali e internazionali sull'educazione. Roma: Armando.

Gozzer, G. (1976). I/ capitale invisibile. L'epoca dei grandi confronti. (1975-76). Roma: Armando.

Gozzer, G. (1980). Il capitale invisibile. L'epoca dei ripensamenti (1977-1980). Roma: Armando.

Malizia, G. (2008). Educazione Comparata. In Prellezo, J.M., Malizia G., \& Nanni, C. (eds.), Dizionario di scienze dell'educazione, (pp. 379-382). Roma: LAS.

Matasci, D., Bandeira Jeronimo, M., Gonçalves Dores, H., (eds.). (2020). Education and Development in Colonial and Postcolonial Africa. Policies, Paradigms and Entaglements $1890_{s}-1980_{s}$. Cham: Palgrave Macmillan.

Monti, L. (2013). Una scuola in movimento: II Puntoemme. In Farina L. (ed.) La casa delle meraviglie. La Emme Edizioni di Rosellina Archinto (pp. 151-154). Milano: Topipittori.

Niccolai, R., (1998). Quando la Cina era vicina: la rivoluzione culturale e la sinistra extraparlamentare in Italia negli anni '60 e '70. Pisa: BFS.

Olmos, L.E., \& Torres, C.A. (2009). Theories of the State, Educational Expansion, Development and Globalization: Marxian and Critical Approaches. In Cowen, R., Kazamias, A.M., (eds.). International Handbook of Comparative Education. (pp. 7386). London - New York: Springer.

Palomba, D. (2011). Gli studi comparativi in educazione: un'introduzione storico-critica. ECPS Journal. (4), 29-45.

Perotti, D. (1981). II mito cinese nella nuova sinistra italiana (1960-1970). II Politico. XLVI (1-2). 223-280.

Terrusi, M. (2019). L'albo illustrato : una panoramica fra storia, storie, visioni e contemporaneità. In Barsotti, B \& Cantatore, L. (eds.), Letteratura per l'infanzia. Forme, temi e simboli del contemporaneo. (pp. 167-183). Roma: Carocci. 
Tosi, L. (1999). L'Italia e le organizzazioni internazionali: diplomazia multilaterale nel Novecento. Padova: Cedam.

Unesco. Commission internationale sur le développement de l'éducation. (1973). Rapporto sulle strategie dell'educazione. Roma: Armando.

Ventrone, A. (2013). "Vogliamo tutto". Perché due generazioni hanno creduto nella rivoluzione. Roma - Bari: Laterza.

Zago, G. \& Callegari C. (2016). L'educazione comparata: una tradizione disciplinare. In Barbieri, N.S., Gaudio, A., \& Zago, G. (eds.), Manuale di educazione comparata: insegnare in Europa e nel mondo (pp. 7-42). Brescia: La Scuola.

Ziglio, C. (1977). Sistemi politici e strutture scolastiche. La scuola secondaria superiore in Europa tra socialismo e capitalismo. Milano: Emme Edizioni.

Zizioli, E. (2011). Armando Armando. Un pedagogista editore. Roma: Anicia. 